\title{
MEMAHAMI DAN MEMPERLAKUKAN LINGKUNGAN DENGAN KACA MATA FILSAFAT
}

\author{
Zainul Muhibbin*
}

\begin{abstract}
Abstrak
Hal yang sering menjadi problematika dan bahan diskusi panjang adalah masalah kelestarian alam. Permasalahan ini sangat berkaitan dengan sikap manusia terhadap alam; bagaimana manusia seharusnya memahami dan bersikap terhadap alam dan lingkungan sekitarnya. Hal inilah yang ingin dikaji dan diteliti untuk menemukan jawabannya. Kajian ini menggunakan pendekatan filsafat dari pemikiran para tokoh filsafat modern. Hasilnya: Prinsip Pansubyektifitas Whitehead, Wahdat al-wujud (makhluk) Mulla Shadra, dan Kesatuan ego (individu) lqbal hendaknya dapat menjadi dasar untuk menumbuhkan kesadaran setiap pribadi manusia sebagai sama-sama subyek dengan unsur-unsur alam yang lain, sehingga tidak ada sikap semena-mena yang eksploitatif terhadap alam dan lingkungan, karena hal itu dapat mengakibatkan ketidakharmonisan general (disharmoni global). Ketika manusia menganggap bahwa lingkungan (alam) di sekitarnya adalah obyek, maka dapat memberi konotasi manusia boleh melakukan eksploitasi sesuka hati terhadap alam. Akan tetapi jika manusia menyadari bahwa seluruh unsur alam ini adalah sesama makhluk, sesama individu, dan sama-sama subyek yang saling terkait, maka tidak ada alasan bagi manusia untuk boleh berbuat ketidakadilan (dhalim) dan kerusakan terhadap alam.
\end{abstract}

Kata kunci: Filsafat, manusia, alam, lingkungan.

Filsafat dipelajari untuk memahami bagaimana manusia berpikir dan bertindak. Pemahaman dan tindakan manusia sering dipengaruhi dan ditentukan oleh aliran berpikir yang dianutnya serta etika yang dipahaminya. Manusia selalu berpikir ketika menghadapi suatu kejadian di hadapannya, atau karena ingin tahu terhadap sesuatu. Dari sini kemudian muncul berbagai pertanyaan di dalam benaknya: Apakah kehidupan itu? Apakah alam itu? Apa dan bagaimana kehidupan dalam alam ini? Apakah semua ini terjadi dengan sendirinya atau karena mekanisme, ataukah memang ada yang merencanakan? Apa hakikat dari realitas ini? Semua permasalahan tersebut membutuhkan jawaban, dan jawaban serta pemecahannya telah melahirkan teori-teori dan sistem pemikiran filosofis, seperti empirisme, fenomenalisme, idealisme, materialisme dan sebagainya.

Idealisme merupakan salah satu aliran dalam filsafat. Idealisme adalah suatu pandangan dunia atau metafisik yang mengatakan bahwa realitas dasar terdiri atas, atau sangat erat hubungannya dengan ide, pikiran (mind) atau jiwa (self). Dunia

\footnotetext{
* Dosen pada UPM Soshum ITS

jsh Jurnal Sosial Humaniorah, Vol 3 No.2, November 2010 
mempunyai arti yang berlainan dari apa yang tampak pada permukaannya. Dunia dipahami dan ditafsirkan oleh penyelidikan tentang hukum-hukum pikiran dan kesadaran, dan tidak hanya oleh metode ilmu obyektif semata-mata. Jika materialisme mengatakan bahwa materi adalah hakikat dari realitas dan ide adalah fenomena yang menyertainya, maka idealisme mengatakan bahwa ide itulah hakikat dari realitas dan materi merupakan produk sesudahnya.

Filosof idealis pertama yang dikenal memiliki teori ide secara sistematis adalah Plato (Hatta, 1996: 44). Dalam sejarahnya, idealisme mengalami perkembangan cukup dinamis karena telah menghasilkan pemikiran-pemikiran filosofis mencakup berbagai teori yang berbeda walaupun tetap memiliki keterkaitan. Idealisme subyektif (immaterialisme), idealisme obyektif dan idealisme personal (personalisme) merupakan jenis-jenis idealisme sebagai hasil dari perkembangan filsafat. Idealisme subyektif berprinsip bahwa akal, jiwa dan persepsi-persepsinya atau ide-idenya merupakan segala yang ada, tetapi hanya ada dalam akal yang mempersepsikannya. Idealisme subyektif ini disebut immaterialisme oleh Berkeley (1665-1753). Dia mencanangkan teori immaterialisme atas dasar prinsip-prinsip empirisme. Ia berpendapat bahwa sama sekali tidak ada substansi-substansi material, yang ada hanyalah pengalaman dalam ruh saja (Praja, 2005: 111).

Idealisme obyektif mengatakan bahwa semua bagian alam tercakup dalam suatu tata tertib yang meliputi segala sesuatu. Kelompok ini menisbatkan kesatuan tersebut kepada ide dan maksud dari suatu Akal yang mutlak (Absolute Mind). Pikiran adalah esensi alam, dan alam adalah keseluruhan jiwa yang diobyektifkan. George Wilhelm Friedrich Hegel (1770-1831) merupakan salah seorang tokoh dari kelompok ini, dia sangat mementingkan rasio dalam filsafatnya. Tema filsafat Hegel adalah Ide Mutlak. Yang dimaksud rasio bukan saja rasio pada manusia dalam arti perorangan akan tetapi juga rasio pada Subyek Absolut. Menurut Hegel, realitas seluruhnya harus disetarakan dengan suatu subyek. Sebuah dalil Hegel yang terkenal berbunyi: "Semuanya yang riil bersifat rasional dan semua yang rasional bersifat riil" (Praja, 2005: 129), ini berarti bahwa luasnya rasio sama dengan luasnya 
realitas. Adapun idealisme personal (personalisme) muncul sebagai protes terhadap materialisme mekanik dan idealisme monistik. Bagi seorang personalis, realitas dasar itu bukanlah pemikiran yang abstrak atau proses pemikiran yang khusus, akan tetapi ia adalah seseorang, suatu jiwa atau seorang pemikir.

Idealisme merupakan aliran yang sangat penting dalam sejarah perkembangan pemikiran manusia. Sebagaimana telah disinggung di atas, idealisme dalam filsafat Barat mula-mula kita temui dalam bentuk ajaran yang murni tentang ide dari Plato. Dapat dikatakan, sepanjang sejarahnya paham idealisme tidak pernah hilang sama sekali, bahkan pernah paham ini menjadi dasar pemikiran manusia yang paling dominan, yaitu pada masa perkembangan filsafat berada di tangan para filosof di dunia Islam. Segenap kaum agamis memang dapat digolongkan ke dalam penganut aliran idealisme yang paling setia. Aliran ini terus berkembang luas dengan dinamika dan kemajuannya hingga abad-abad modern. Diantara filosof idealis modern yang perlu kita kenal dan kaji filsafatnya adalah Whitehead dari Barat, disamping Shadra dan Iqbal dari kalangan Islam.

\section{Idealisme Whitehead}

Alfred North Whitehead, dia adalah filosof Inggris yang lahir di East Kent, Inggris pada tahun 1861, dan meninggal di Cambridge, Massachusetts pada tahun 1947. Pengalaman hidupnya sejak masa kanak-kanak telah memberi dia kesan yang sangat dalam dan pengertian yang kuat tentang kesinambungan dalam kehidupan masyarakat dari generasi ke generasi (Urmson, 1991: 323). Bekerjasama dengan Bertrand Russel, dia menulis bidang dasar-dasar logika matematika dan melahirkan tiga volume buku Principia Mathematica (1910-1913) yang monumental, bahkan ini menjadi puncak perkembangan logika simbolik. Sebenarnya interes ini telah tampak pada karya Whitehead yang berjudul Treatise on Universal Algebra (1903) dan pada Mathematical Concepts of The Material World (1905) (Lacey, 1996: 383). Dari perjalanan karirnya sebagai ilmuwan dan pemikir, serta perannya sebagai guru besar filsafat di Universitas Harvard, Whitehead kemudian tercatat sebagai salah seorang filosof terkemuka di dunia filsafat Barat modern. 
Filsafat Whitehead pada dasarnya merupakan kombinasi dari tiga garis pokok pemikiran, yaitu: (1) Sistem relasi abstrak yang terinspirasi dari logika matematika, (2) Kosmologi yang merupakan sintesa antara pengetahuan fisik dan dunia metafisik sebagai sebuah proses, dan (3) Moral, agama dan estetika dalam hubungan kemanusiaan adalah sebagai bagian dari unsur-unsur realitas. Tawaran dan upaya ini dinilai sebagai spekulasi yang sangat berani dalam dunia metafisika dan teori umum realitas. Filsafat Whitehead ini berfokus pada; dengan apakah keberadaan di dunia ini terjadi dan bagaimana realitas ini dimengerti.

\section{The Method of Extensive Abstraction}

Ide Whitehead pada garis pemikiran (pertama) ini sangat dilatarbelakangi oleh penguasaannya dalam bidang matematika. Menurutnya, matematika adalah berasal dari hubungan logika formal yang pasti. Oleh karena itu upaya membuat pengembangan terhadap sistem deduktif, dalam hal ini, merupakan sesuatu yang mungkin dan terbuka lebar, format kemungkinan itu bahkan mengundang masuknya nilai-nilai aplikasi empirik ke dalamnya (Benton, 1965: 498). Inilah yang menjadi pintu masuk teori relasi abstrak. Whitehead tampaknya ingin bermaksud bahwa teori-teori matematis dapat diaplikasikan untuk melihat gejala-gejala sosial sebagai pengalaman empirik dalam masyarakat.

Ide general Whitehead telah mendasari pengetahuan dan pemahaman terhadap alam fisika. Bagi Whitehead, sebuah ukuran perubahan yang terus menerus mengalir dari satu peristiwa natural kepada yang lainnya adalah menyangkut energi (Urmson, 1991: 324). Dari sini berarti keberadaan alam raya ini tidaklah statis, melainkan terus bergerak secara kontinyu dan otomatis (tanpa henti), pergerakan itu terjalin dalam sistem relasi yang luas, dan relasi itu bersifat abstrak. Jalinan relasi itu menghubungkan partikel-partikel sebagai unsur natural dalam sebuah abstraksi luas.

Abstraksi luas tersebut sebagai metode adalah suatu sifat dari relasi pada terma-terma yang bermacam-macam, ini seperti "lingkaran” bujur sangkar atau bulatan besar (Benton, 1965: 498). Analogi ini sebenarnya lebih merupakan penegasan saja, bukan sebagai elemen-elemen geometri yang sebenarnya, ini untuk 
menggambarkan bagaimana sebenarnya jalan pemikiran di atas. Singkatnya, sistem relasi abstrak yang luas itu kemudian disebut The Method of Extensive Abstraction.

\section{Philosophy of Organism (Process)}

Keberadaan alam, dalam filsafat Whitehead, dipahami sebagai relasi yang saling berkaitan dan bisa juga secara timbal balik yang sistematis antara satu unsur dengan yang lainnya. Logika dasarnya adalah berangkat dari relasi "keseluruhan dan bagian" (Whole and Part), dan proses relasinya terjadi secara berkesinambungan berdasarkan mengalirnya waktu, atau bisa juga secara overlapping yang sistematis, merupakan "hubungan luas" (Extensive Connexion) antara pemahaman metafisik dengan data inderawi. Dalam koneksi tersebut selalu terjadi proses perubahan dan perkembangan dalam alam (Urmson, 1991: 324). Prinsip Whole and Part tersebut memberi pengertian bahwa alam ini bergerak secara organis dan saling terkoneksi di antara unsur-unsurnya; keseluruhan realitas tidaklah sama dengan penjumlahan unsur-unsur bagiannya, karena pandangan Whitehead tidaklah monisme, melainkan tetap dalam keragaman dan pluralitas realitas.

Koneksi luas itu dapat dikatakan sebagai sintesa antara teori kosmologis dan evolusionary pada satu sisi dengan pandangan agama dan metafisika pada sisi lain. Prosesnya dapat digambarkan sebagaimana "perasaan" yang berisi sebuah interpretasi tentang dunia, kemudian dikaitkan dengan persepsi umum sehingga mendasari pengetahuan fisik. Ini adalah sebuah kosmologi bagi Whitehead. Demikian juga dengan "pengalaman", menurut dia, pengalaman datang kepada kita bermula dari kejadian pertama dalam format samar-samar yang bertalian secara kontinyu dengan perasaan-perasaan, dan ini sama sekali tidak dalam format potonghabis (clear-cut) dengan data inderawi, melainkan proses itu terjadi secara berkesinambungan dan serasi (Urmson, 1991: 324).

Whitehead mengklaim bahwa skema logikanya ini akan dapat mencapai sebuah proses idealisasi dan abstraksi dari data mentah sebuah pengalaman. Pada kesempatan lain (berikutnya) Whitehead mempresentasikan laporan tentang "keterkaitan alam" dalam terma-terma sebuah skema logika yang didasarkan pada dugaan (konsep) Extensive Connexion. Dia merubah konstruksi sistem metafisika 
komprehensif, didasarkan pada dugaan-dugaan ini, menjadi berpusat pada terjadinya entitas aktual (actual entity), yaitu sesuatu yang benar-benar ada secara aktual dalam proses pengembangan dalam alam (Urmson, 1991: 324). Entitas aktual ini dapat juga dikatakan sebagai peristiwa aktual, karena setiap satuan aktual merupakan suatu peristiwa pengalaman, atau juga suatu proses perwujudan diri menjadi satu individu (subyek). Entitas aktual itu adalah manusia, binatang, sel, partikel-partikel atom dan lain-lain, bahkan Tuhan (Heriyanto, 2003: 180).

"Entitas aktual" Whitehead, bagaimaapun juga, adalah tidak "tanpa jendela" (tertutup) akan tetapi tetap terbuka sebagai proses dalam interaksi aktif dengan setiap keseluruhan unsur alam yang lain. Whitehead melihat masalah ini sebagai dugaan umum (general) tentang interkoneksi organik. Dan sesungguhnya dia mendeskripsikan proyek ini sebagai sebuah Philosophy of Organism (Filsafat Organisme) atau dikenal juga sebagai Filsafat Proses (Urmson, 1991: 325).

Secara keseluruhan, terhadap filsafat orgamisme yang dicanangkan tersebut, Whitehead, sebagaimana dikutip Husein Heriyanto dari "Process and Reality", menegaskan:

Tujuan filsafat organisme adalah untuk mengungkapkan sebuah kosmologi yang koheren yang didasarkan pada gagasan tentang 'sistem', 'proses', 'kemajuan kreatif kepada kebaruan', 'kesatuan pengalaman individual', 'perasaan', 'waktu sebagai laju tiada henti', 'kestabilan sebagai penciptaankembali' dan 'terarah-kebertujuan' (Heriyanto, 2003: 179).

Secara sistemik filsafat organisme ini sangat menekankan prinsip proses, oleh karena itu filsafat ini dikenal juga sebagai Filsafat Proses.

\section{Reality}

Dalam mendeskripsikan realitas, sebagai pokok pikiran ketiga, Whitehead memulai dengan penggunaan terminologi terpadunya aspek-aspek biologis dengan psikologi introspektif, seperti "feeling” yang digunakan untuk sebuah perasaan general yang kuat. Selanjutnya dia mencoba mengkombinasikan logika, psikologi, estetika, matematika, biologi dan fisika, serta pandangan religius (agama) dalam skema yang sama. Semuanya dideskripsikan sebagai elemen-elemen proses pada realitas dalam alam. Dia berharap semua ini akan menjadi prinsip metafisika yang 
sangat general. Dia bermaksud membuat skema generalisasi prinsip-prinsip yang diambil dari berbagai sumber (elemen) (Urmson, 1991: 325). Konkretnya, realitas adalah kesatuan sistem yang utuh terdiri dari berbagai unsur, baik fisik maupun metafisik, yang tidak statis melainkan terus bergerak tanpa henti dan saling terkait.

Jadi, filsafat Whitehead ingin mengungkapkan bahwa realitas ini terdiri dari unsur-unsur, yaitu satuan-satuan aktual (entitas aktual), baik yang terkategori fisik (materi) maupun non fisik (immateri), yang semuanya terpadu dalam proses menyeluruh dan bergerak tanpa henti dalam ruang-waktu yang general. Menurut Whitehead, tidak ada sesuatupun yang lebih nyata dan primer dari pada entitas aktual. Realitas dipahami berdasarkan entitas aktual, dan entitas aktual merupakan kategori eksistensi primer yang membentuk segala sesuatu yang ada. Ini merupakan prinsip ontologis (Heriyanto, 2003: 180). Entitas aktual, sebagaimana telah disinggung pada pembahasan sebelum ini, adalah mencakup satuan-satuan seperti manusia, binatang, partikel-partikel atom, moral, logika, hal psikologis dan lain-lain, bahkan Tuhan.

Berkaitan dengan upaya memadukan aspek-aspek materiil dan immateriil, dalam kosmologi Whitehead yang organis dan vitalistik, terdapat terminologi yang prinsipil, yaitu apa yang disebut sebagai pansubyektivitas (pansubjectivity). Menurut Whitehead, prinsip pansubyektivitas berlaku untuk semua entitas aktual, mulai dari Tuhan, moralitas, psikologis (immateri), manusia, hewan, tumbuhan (biologis), mineral sampai benda-benda mati (fisikal). Maksudnya, semua yang ada di alam ini harus dipahami dan diperlakukan sebagai subyek (Heriyanto, 2003: 187). Ini berarti tidak ada dikotomi antara manusia sebagai subyek dan alam lingkungan sebagai 'obyek'. Dalam prinsip pansubyektivitas ini justru ditekankan bahwa setiap yang ada, termasuk benda-benda mati, adalah subyek. Ini sebuah prinsip dasar ekosistem yang dinamis dan serasi. Oleh karena itu tidak ada alasan bagi manusia untuk bersikap dan berbuat eksploratif dan eksploitatif terhadap alam dan lingkungan tanpa pertimbangan etika, estetika dan nilai-nilai religius.

Whitehead juga memberi perhatian kepada agama dalam relasi unsur-unsur realitas di atas. Menurutnya, agama tidak hanya bersifat sosiologis melainkan juga sebagai kegelisahan hubungan manusia kepada Tuhan dalam aktivitas sehari-hari 
yang permanen dalam proses dunia. Agama dan doktrinnya berposisi sebagai sistem general yang memberi efek (effect) dalam transformasi karakter (Whitehead, 1966: 97). Hubungannya dengan fenomena sosial dan ritual dalam agama tidak hanya memberi stimulasi pada emosi, tetapi juga sebagai keterangan (petunjuk) yang memadai dalam penggunaannya sebagai terapi dalam hubungannya dengan penyakit-penyakit sosial yang menyebabkan ketidakserasian (Whitehead, 1966: 100).

\section{Shadra Dan Wahdat Al-Wujud}

Shadra adalah tokoh tasawuf falsafi penting dalam perkembangan filsafat metafisika Islam. Dia adalah Muhammad bin Ibrahim Al-Qawami, lebih dikenal dengan sebutan (gelar) Shadr ad-Din asy-Syirazi atau Mulla Shadra. Lahir di Syiraz pada tahun 1571 dan meninggal di Bashrah pada tahun 1640 (Al-Hafni, 1999: 829). Pemikiran Mulla Shadra sebenarnya berfundasi pada dua keilmuan sekaligus, yaitu tasawuf dan filsafat, dan yang menjadi fakus perhatian kajian ini adalah wahdatul wujud perspektif Mulla Shadra, yang merupakan bagian dari metafisika dalam filsafat.

Hal baru yang merupakan temuan Shadra adalah konsep filosofi yang dia sebut Al-Hikmah Al-Muta'aliyah (Teosofi Transenden). Dasar Al-Hikmah AlMuta'aliyah adalah "ilmu" tentang wujud (yang "ada"). Istilah wujud digunakan untuk menyebut Wujud mutlak (absolut), murni dan hakiki, yaitu Tuhan, dan wujud nisbi yaitu makhluk. Substansi wujud adalah tatanan eksistensi yang padu dan teratur, wujud ini bagaikan cahaya yang di dalamnya memiliki intensitas dan kemampuan, keanekaragaman, kekuatan dan pergerakan. Bagi Shadra, poros wujud dipahami sebagai; wujud jagad raya dengan keanekaragamannya yang tak terhingga tidak hanya dipersatukan oleh tatanan yang berpusat pada Wujud Yang Satu, melainkan juga pada keterpaduan dan keteraturan alam (Nasr, 1991). Inilah yang disebut Wahdat al-wujud. Oleh karena itu wujud merupakan kesatuan dalam keragaman dan keragaman dalam kesatuan. 
Wahdat al-wujud bagi Shadra, adalah kesatuan antara Wujud Mutlak (Tuhan) dengan wujud nisbi (alam) secara langsung. Dalam madzhab pemikiran Mulla Shadra, wujud alam (makhluk), jika dibandingkan dengan wujud Tuhan, bukanlah wujud yang hakiki. Makhluk disebut sebagai bayangan, citra dan manifestasi. Makhluk ini secara substansial tidak menampakkan dirinya sendiri akan tetapi merupakan "penampakan" Tuhan. Makhluk adalah citra, bayangan dan manifestasi Tuhan (Marwah, 2002: 191). Dengan demikian makhluk bukanlah suatu wujud mandiri karena dengan perantaraannya Tuhan tercitrakan dan terbayangkan, ia adalah manifestasi Tuhan itu sendiri.

Perbedaan wujud Tuhan dan makhluk tidak dipahami sebagai dua realitas yang memiliki garis pembatas dan pemisah, melainkan perbedaan antara keduanya terletak pada kesempurnaan Tuhan dan ketidaksempurnaan makhluk, kekuatan-Nya dan kelemahannya. Oleh karena itu, perbedaan antara keduanya bukan perbedaan yang saling berhadapan dan bersinggungan melainkan perbedaan yang bersifat "mencakupi" dan "meliputi". Kesatuan segala "wujud tercipta" (maujud) yang beraneka ragam tapi terpadu dalam satu kesatuan yang tak terpisahkan tercakup dalam kesatuan realitas Wujud yang "meliputi” (Marwah, 2002: 193). Dengan kata lain, segala wujud yang terciptakan merupakan suatu rangkaian gradasi sejajar dari manifestasi cahaya substansi dan atribut-Nya dan bukan sebagai realitas maujud yang mandiri dan terpisah secara esensial dari sang Wujud. Dalam keanekaragaman maujud yang terpadu dalam satu kesatuan, masing-masing unsurnya adalah dalam posisi yang sama dan sejajar sebagai makhluk.

\section{Metafisika Iqbal}

Muhammad Iqbal adalah pemikir asal Punjab, lahir di Sialkot pada tahun 1876. Pendidikannya dimulai dari daerah asalnya, kemudian meneruskan ke Lahore hingga memperoleh gelar Magister. Selanjutnya dia mendalami filsafat di Universitas Cambridge, Inggris. Kemudian pindah ke Munich, Jerman, sampai bergelar Ph.D. Iqbal dikenal sebagai pemikir, penyair, filosof dan tokoh pembaharu di dunia Islam. Iqbal meninggal dunia pada usia 62 tahun, tepatnya pada tahun 1938 (Nasution, 1987: 190). 
Pemikiran metafisika Iqbal menunjukkan adanya segi-segi perbedaan dengan pendekatan metafisika Persia yang panteistik. Aspek utamanya adalah sebagai berikut:

1. Filsafat Wahdat al-wujud perspektif metafisika Persia dipahami sebagai sesuatu yang telah sempurna dan sudah jadi, sedangkan dalam filsafat Iqbal dikatakan bahwa alam semesta masih dalam proses "menjadi" atau penyempurnaan (dinamis).

2. Wahdat al-wujud, sebagaimana terkandung dalam tata namanya, adalah hakikat kesatuan wujud, dan realitas alam semesta adalah kesatuan maujud yang sama, sedangkan dalam filsafat Iqbal kita dapati suatu pendekatan yang pluralistik dalam melihat realitas alam global.

3. Dalam Wahdat al-wujud yang terdahulu, kebebasan kehendak manusia tidak ada (disinggung), sedangkan salah satu aspek penting filsafat Iqbal adalah konsep kebebasan nyata bagi setiap ego atau "diri" manusia yang demikian besar sehingga lewat kebebasan ini hakikat realitas puncak (ultimate reality) dibukakan (Iqbal, 1992: 31).

Iqbal memandang alam semesta ini bukan sebagai suatu produk yang sudah selesai dan sempurna, tetapi sedang berada dalam tahap-tahap "terus menjadi". Menurut dia, tidak sesuatupun tentang hal ini dapat dikatakan dengan tegas, dogmatis, telah final. Penciptaan adalah sebuah proses yang berkelanjutan; manusia turut ambil bagian dalam proses itu dan setiap saat menciptakan situasi-situasi dan produk-produk baru. Alam semesta merupakan suatu kumpulan individu-individu atau ego, jumlah ego ini belum “ditentukan”. Dalam setiap unit temporal, individuindividu baru ditambahkan, dan pada gilirannya menambah aktivitas penciptaan. Kehidupan bukanlah sesuatu yang telah jadi; keinginan-keinginan, hasrat-hasrat baru selalu menciptakan perubahan-perubahan baru dalam alam. Tidak ada sesuatu yang tetap dalam kehidupan ini kecuali perubahan. Ia terus menerus dalam keadaan menjadi, berkelanjutan, dinamis sebagai evolusi kreatif (Saiyidain, 1981: 87). 
Metafisika Iqbal dapat dipahami bahwa, kehidupan sebagai realitas alam semesta yang fundamental, pada mulanya berupa kekuatan instinktif buta, sama sekali tanpa tujuan. Ketika kehidupan ini dihadapkan dengan materi dan menimbulkan kekuatan responsif, ia belajar untuk memanjat tangga evolusi. Setelah mengembara dalam keliaran wujud akhirnya ia menemukan kekuatan memahami nilai-nilai. Kesadaran nilai merupakan perubahan yang revolusioner dalam pola kehidupan dan menjadi miliknya yang paling berharga. Pengembangan nilai-nilai, norma dan tujuan memberikan "penjajaran" yang aktual dengan yang Ideal (Ali, 1998: 174). Sementara itu, pluralitas aktual yang dinamis terpadu dalam satu kesatuan yang tak terpisahkan sebagai individu-individu. Alam semesta merupakan kumpulan individu-individu (ego), dan Tuhan adalah satu individu, hanya saja Dia adalah Individu Sempurna. Individu-individu tersebut adalah ego-ego aktual dengan aktivitas kretif yang terpadu dalam keterkaitan tak terpisahkan, ini merupakan hakikat pergerakan dinamis.

\section{Alam Bagi Whitehead, Shadra Dan Iqbal}

Untuk lebih memahami makna filosofis pemikiran para tokoh di atas, tentang alam dan lingkungan, perlu kita membandingkan idealisme mereka, yaitu Whitehead, Shadra dan Iqbal. Antara Whitehead, Mulla Shadra dan Muhammad Iqbal terdapat sisi persamaan dalam pandangan filosofis mereka, misalnya pada pandangan linier-progresif, di sini terdapat kemiripan, yaitu sebagai konsekuensi alamiah dari dua premis; 1) Alam pada esensinya adalah gerak, dan 2) Waktu merupakan dimensi inhern yang tak terpisahkan dari alam. Di samping itu ada perbedaan diantara meraka, yaitu Shadra berpendapat bahwa gerak itu lebih dipahami sebagai evolusi menuju kesempurnaan, sementara Whitehead lebih menekankan bahwa gerak itu kontinyu sebagai proses untuk "menjadi”, dalam hal ini Whitehead sama dengan Iqbal, bahkan proses "menjadi" itu merupakan pergerakan tiada henti.

Selain itu yang mirip diantara mereka adalah, bahwa mereka tidak jatuh pada pandangan yang monistik mutlak. Whitehead dan Iqbal tetap mempertahankan prinsip keragaman dan pluralitas dalam realitas, meskipun Shadra hanya memberi 
penegasan keragaman realitas tanpa penekanan pluralitas. Whitehead dan Shadra adalah dua filosof yang memiliki kesamaan dalam kemampuannya menggabungkan kecakapan refleksi metafisika spekulatif yang mendalam dengan kecakapan analisis yang tajam, meskipun tidak meninggalkan realitas. Sementara metafisika Iqbal lebih berangkat dari realitas dengan menggunakan idealismenya. Karakteristik pemikiran mereka cenderung sama karena memiliki titik temu, yaitu kosmik, realis, dinamis dan holistik. Semuanya sama-sama memandang alam pada esensinya sebagai gerak; kontinyu dan terpadu.

Satu hal lagi yang perlu disimak adalah pandangan mereka tentang esensi alam atau substansi realitas. Whitehead, pada intinya berpendapat bahwa alam dan keseluruhan realitas ini adalah terdiri dari unsur-unsur, yaitu satuan-satuan aktual (entitas aktual), baik yang terkategori fisik (materi) maupun non fisik (immateri), yang semuanya terpadu dalam proses menyeluruh dan bergerak kontinyu dalam ruang-waktu yang general. Entitas aktual itu mencakup satuan-satuan seperti manusia, binatang, tumbuhan, partikel-partikel atom, material, moral, logika, hal psikologis dan lain-lain, bahkan Tuhan. Seluruh unsur tersebut, baik yang materiil maupun immateriil, dalam kosmologi Whitehead diterminologikan sebagai apa yang disebut pansubyektivitas. Prinsip pansubyektivitas ini berlaku untuk seluruh entitas aktual, baik yang biologis, fisikal, psikologis bahkan immateri, semuanya harus dipahami dan diperlakukan sebagai subyek. Ini berarti tidak ada dikotomi antara manusia sebagai subyek dan alam lingkungan sebagai obyek. Dalam prinsip ini disikapi semua yang ada sebagai subyek, tanpa kecuali.

Mulla Shadra menganggap bahwa substansi realitas adalah "kesatuan yang ada" (Wahdat al-wujud), hanya saja Wujud Mutlak (Tuhan) berbeda dengan wujud nisbi (makhluk), dan perbedaan antara keduanya bukan perbedaan yang saling berhadapan dan bersinggungan melainkan perbedaan yang bersifat "mencakupi" dan "meliputi". Kesatuan segala "wujud tercipta" (maujud) yang beraneka ragam tapi terpadu dalam satu kesatuan yang tak terpisahkan tercakup dalam kesatuan realitas Wujud yang “meliputi”. Dengan kata lain, segala wujud yang terciptakan merupakan suatu rangkaian gradasi sejajar dari manifestasi cahaya substansi dan atribut-Nya 
dan bukan sebagai realitas maujud yang mandiri dan terpisah secara esensial dari sang Wujud. Dalam keanekaragaman maujud yang terpadu dalam satu kesatuan, masing-masing unsurnya adalah makhluk. Karena sama-sama makhluk maka masing-masing unsur maujud itu harus memposisikan dirinya sebagai "sesama", tidak peduli apakah itu manusia, binatang, tumbuhan, tanah, udara, air dan sebagainya.

Sementara itu Iqbal berpendirian bahwa esensi kehidupan alam adalah; alam semesta ini bukan sebagai suatu produk yang sudah jadi dan selesai, tetapi sedang berada dalam proses "menjadi". Menurut dia, tidak sesuatupun tentang hal ini dapat dikatakan dengan tegas, dogmatis, telah final. Alam semesta merupakan suatu kumpulan individu-individu atau ego, jumlah ego ini belum "ditentukan". Dalam setiap unit temporal, individu-individu baru ditambahkan, dan pada gilirannya menambah aktivitas penciptaan. Kehidupan bukanlah sesuatu yang telah jadi. Ia terus menerus dalam keadaan menjadi, berkelanjutan, dinamis sebagai evolusi kreatif. Oleh karena semua unsur alam ini adalah individu, maka satu individu tidak boleh melakukan sesuatu yang tidak sepantasnya terhadap individu lain, karena mereka adalah satu kesatuan yang plural tapi terpadu tak terpisahkan.

Menarik sekali mengkaji pemikiran filsafat tiga tokoh di atas, mereka memiliki banyak kesamaan meskipun terdapat perbedaan pada beberapa sisi. Satu hal yang penting dan sama dari mereka adalah pada pendirian bahwa realitas alam ini tidaklah statis melainkan secara esensial adalah gerak. Pergerakan itu terjadi secara kontinyu tanpa henti sebagai sebuah proses, dan satu unsur dengan yang lainnya saling terkait secara timbal balik dan dinamis dalam keanekaragaman unsurunsur alam.

Perbedaan diantara mereka hanyalah pada penggunaan istilah, sementara makna esensialnya adalah sama. Whitehead menggunakan pansubyektivitas untuk kesatuan unsur-unsur alam sebagai entitas aktual, semuanya diperlakukan sebagai subyek tanpa kecuali, sehingga tidak boleh satu unsur mengaggap dirinya subyek dan menganggap yang lain sebagai obyek. Shadra menggunakan kesatuan makhluk (Wahdat al-wujud dalam konteks maujud), yang mengandung makna bahwa semua unsur alam ini adalah makhluk (yang tercipta), oleh karena itu satu makhluk dengan 
makhluk yang lain, apapun bentuknya, tidak boleh melakukan hal yang tidak semestinya sehingga merusak kesatuan makhluk, dan akhirnya alam pun rusak. Sementara Iqbal menggunakan kesatuan individu (ego) sebagai unsur alam yang plural tapi terpadu. Seluruh unsur dalam alam ini adalah individu-individu aktual; manusia, binatang, tumbuhan dan segala macam benda adalah individu. Oleh karena itu satu individu dengan individu yang lain harus terpadu secara permanen. Jika keterpaduan rusak disebabkan adanya individu yang memposisikan dirinya "lebih" dari pada yang lain maka rusaklah alam ini.

“Subyek”nya Whitehead, "makhluk"nya Shadra dan "individu”nya Iqbal substansinya adalah sama. Jika diintegrasikan maka premisnya adalah: Segala unsur alam ini adalah makhluk, semua makhluk adalah individu, dan semua individu adalah subyek. Satu makhluk sebagai unsur alam ini adalah individu dan subyek, eksistensinya dalam alam ini memiliki lingkungan di sekitarnya, apapun yang ada di sekitarnya (lingkungan) adalah makhluk, dan dia itu adalah individu yang sekaligus sebagai subyek. Oleh karena itu, tidak sepantasnya satu individu sebagai subyek merusak individu lain karena memperlakukannya sebagai obyek.

Manusia, binatang, tumbuhan, tanah, udara, air dan semua benda alam ini adalah makhluk, individu dan subyek. Jika manusia merusak lingkungannya maka akan terjadi disharmoni, dan merusak dinamika keterpaduan dan kesatuan realitas. Oleh karena itu, manusia harus memahami dan menjaga alam lingkungannya sebagai sesama makhluk dan individu, serta memperlakukan alam lingkungannya sebagai sesama subyek.

\section{Kesimpulan}

Kesimpulan dari pembahasan di atas adalah, bahwa filsafat Whitehead merupakan kombinasi dari tiga garis pokok pemikiran, yaitu sistem relasi abstrak, proses dan realitas. Sementara Mulla Shadra berpijak dari prinsip Wahdat al-wujud dengan pendekatan sufisme filosofis karakteristik Shadra, yaitu teosofi transenden. Sedangkan metafisika Iqbal berangkat dari prinsip kesatuan ego (“diri”), setiap ego 
adalah individu, dan seluruh unsur alam ini adalah individu-individu yang terpadu, bergerak, dinamis, dan berproses untuk “menjadi”.

Setelah menyimak filsafat tiga tokoh di atas, dapat dikatakan bahwa terdapat kesamaan dalam idealisme mereka secara substansif, mereka termasuk orang yang berpendirian bahwa terdapat harmoni antara manusia dengan alam, apa yang tertinggi dalam jiwa juga merupakan yang terdalam dalam alam, pengertian tentang alam fisik merupakan hasil dari pemahaman dalam alam jiwa.

Dari prinsip Pansubyektifitas, atau Wahdat al-wujud (makhluk), ataupun Kesatuan ego (individu), hendaknya dapat menumbuhkan kesadaran setiap pribadi manusia sebagai sama-sama subyek dengan unsur-unsur alam yang lain, sehingga tidak ada sikap semena-mena yang eksploitatif terhadap alam dan lingkungan, karena hal itu dapat mengakibatkan ketidakharmonisan general (disharmoni global). Ketika manusia menganggap bahwa lingkungan (alam) di sekitarnya adalah obyek, maka dapat memberi konotasi manusia boleh melakukan eksploitasi sesuka hati terhadap alam. Akan tetapi jika manusia menyadari bahwa seluruh unsur alam ini adalah sesama makhluk, sesama individu, dan sama-sama subyek yang saling terkait, maka tidak ada alasan bagi manusia untuk boleh berbuat ketidakadilan (dhalim) dan kerusakan terhadap alam.

\section{Daftar Pustaka}

Al-Hafni, Abdul Mun'in,Dr., (1999), Mausu'at Al-Falsafah Wal-Falasifah, vol. 1, Kairo: Maktabah Madbouli.

Ali, H.A. Mukti, (1998), Alam Pikiran Islam Modern di India dan Pakistan, Bandung: MIzan.

Benton, William, (1965), Encyclopaedia Britannica, vol. 21, Chicago: William Benton Publisher.

Hatta, Muhammad, (1980), Alam Pikiran Yunani, Jakarta: Tintamas Indonesia.

Heriyanto, Husein, (2003), Paradigma Holistik: Dialog Filsafat, Sains dan Kehidupan Menurut Shadra dan Whitehead, Jakarta: Teraju.

Iqbal, Muhammad, (1992), Metafisika Persia: Suatu Sumbangan untuk Sejarah Filsafat Islam, ter. Joebaar Ayoeb, Bandung: Mizan. 
Lacey, A.R., (1996), A. Dictionary of Philosophy, London and New York: Roudledge.

Marwah, Husain, (2002), An-Naz'at Al-Madiyah fi Al-Falsafah Al-Arabiyah AlIslamiyah, vol. 3, Beirut: Dar Al-Farabi.

Nasution, Harun, (1987), Pembaharusn dalam Islam: Sejarah Pemikiran dan Gerakan, Jakarta: PT. Bulan Bintang.

Nasr, Sayid Husein, (1991), The Trancendal Theosofi of Sadruddin Asy-Syirazi, ter. Baharuddin Ahmad, Kuala Lumpur: Dewan Bahasa dan Pustaka.

Praja, Juhaya S., (2005), Alran-aliran Filsafat dan Etika, Jakarta: Kencana.

Saiyidain, K.G., (1981), Percikan Filsafat Iqbal Mengenai Pendidikan, ter. Soelaeman, Bandung: CV. Diponegoro.

Urmson, J.O. and Jonathan Ree, ed., (1991), The Concise Encyclopaedia of Western Philosophy and Philosophers, London and New York: Roudledge.

Whitehead, A.N., (1966), "The Elements of Religion", in Justus Buchler and Sterling P. Lamprecht, ed., A Modern Reader in The Philosophy of Religion, New York: Meredith Publishing Company. , (1978), Process and Reality, in David Ray Griffin and Donald W. Sherburne, ad., New York: The Free Press. 